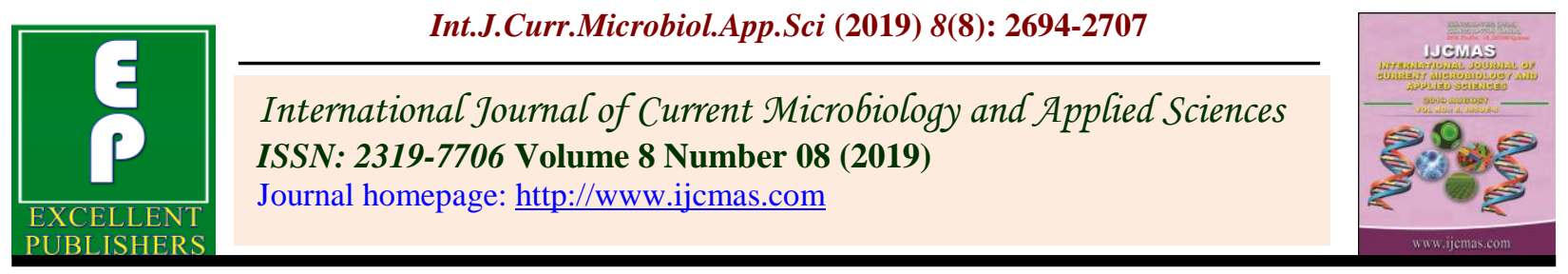

Original Research Article

https://doi.org/10.20546/ijcmas.2019.808.312

\title{
Evaluation of Antioxidative Responses in Cotton (Gossypium hirsutum L.) Genotypes Imparting Resistance to Sucking Pest Attack
}

\author{
Anju Rani, Jayanti Tokas*, Himani and H. R. Singal \\ Department of Biochemistry, College of Basic Sciences and Humanities, CCSHAU, Hisar - \\ 125004 (Haryana), India \\ *Corresponding author
}

\section{A B S T R A C T}

\begin{tabular}{|c|}
\hline Keywords \\
\hline $\begin{array}{l}\text { Antioxidative } \\
\text { enzyme, cotton, } \\
\text { sucking pest, } \\
\text { resistance, yield }\end{array}$ \\
\hline Article Info \\
\hline $\begin{array}{l}\text { Accepted: } \\
\text { 22 July } 2019 \\
\text { Available Online: } \\
10 \text { August } 2019\end{array}$ \\
\hline
\end{tabular}

Present study was investigated to elucidate the role of antioxidative enzymes in imarting resistance to sucking pest attack. Antioxidative enzymes viz. SOD, CAT, POX, GR and APX were estimated in the leaves $\left(2^{\text {nd }}\right.$ leaf $\& 6^{\text {th }}$ leaf $)$ of cotton genotypes infected by sucking pests at 50,60 and 68 days after sowing (DAS) stage. The antioxidative enzyme activity before infection was maximum in $2^{\text {nd }} \&$ $6^{\text {th }}$ leaves of $G$. arboreum genotypes followed by G. hirsutum resistant genotypes and minimum in $G$. hirsutum susceptible genotypes. After infection, antioxidative enzyme activity increased in all the genotypes in both the leaves. The maximum increase in activities of enzymes viz. catalase (CAT), peroxidase (POX), superoxide dismutase (SOD), ascorbate peroxidase (APX) and glutathione peroxidase (GR) were observed in $6^{\text {th }}$ leaves after pests infection. Maximum increase in antioxidative enzymes was observed in HD418 of G. arboreum, H1098 of G. hirsutum (R) and H1454 genotype of G. hirsutum (S). The results suggested that antioxidative enzymes play an important role in providing resistance to sucking pests infection in cotton genotypes.

\section{Introduction}

Cotton is an important cash crop of India. It belongs to the genus Gossypium and family Malvaceae. It is grown in India in about 111.55 lakh hectares as against 92.33 lakh hectares witnessed for the same time last year, thereby indicating an increase of close to 21 per cent in the acreage, with annual production of 337.25 lakh bales of $170 \mathrm{~kg}$ each. Crop loss due to pest and pathogen attack is a serious problem worldwide. The incidence of insect pests considerably reduces both the yield and quality of cotton production. In India sucking pest reduces the crop yield to greater extent (Dhawan et al., 1988). Nath et al., (2000) reported that American cotton is more susceptible to the attack of sucking insect pests as well as bollworm complex than indigenous cotton. However, interestingly, the native cotton Gossypium arboreum and Gossypium herbaceum appears not to be infected with cotton leaf curl disease till the first inception of disease (Akhtar et al., 2010, 
2013). Physiological, morphological, and biochemical changes are observed in the plant in response to sucking pest damage (Agrawal et al., 2009). Biotic and abiotic stresses such as drought, salinity, chilling, metal toxicity, and UV-B radiation as well as pathogens attack lead to enhanced generation of ROS in plants due to disruption of cellular homeostasis (Shah et al., 2001; Sharma and Dubey, 2005). Whether ROS will act as damaging or signaling molecule depends on the delicate equilibrium between ROS production and scavenging. Because of the multifunctional roles of ROS, it is necessary for the cells to control the level of ROS tightly to avoid any oxidative injury and not to eliminate them completely. Higher plants have evolved a complex network of antioxidant systems to counteract elevated ROS levels produced in response to pest infestation. This sophisticated machinery encompasses a wide range of lipid and water-soluble antioxidants (e.g., tocopherols, $\beta$-carotene, ubiquinone, ascorbate, glutathione) and antioxidant enzymes such as superoxide dismutase (SOD), catalase (CAT), glutathione transferase (GST), glutathione peroxidase (GPX), and ascorbate peroxidase (APX) (de Carvalho et al., 2013; Sanchez-Rodriguez et al., 2012). Higher levels of anti-oxidative enzymes such as SOD, CAT, and POX along with polyphenol oxidase (PPO) and phenylalanine ammonia lyase (PAL) were observed in the infested cotton plants. Detailed studies on antioxidant enzymes are important to facilitate our understanding of their role in insect pest resistance. It would, therefore, be the important aim of the cotton breeder to develop cotton genotypes with enhanced protective antioxidative defense system.

\section{Materials and Methods}

The present study was conducted in nine cotton genotypes viz. HD418, HD432, HD503, H1439, H1463, H1454, H1464, H1465 and
H1098 during kharif season at cotton field of Department of Genetics and Plant Breeding, CCS Haryana Agricultural University, Hisar. Analysis of antioxidative enzymes was performed at an interval of 50,60 and 68 days after sowing. Three plants were randomly selected and $2^{\text {nd }} \& 6^{\text {th }}$ leaves were taken before and after infection of sucking pests for estimation for biochemical constituents. The enzymes namely superoxide dismutase, catalase, peroxidase, ascorbate peroxidase and glutathione reductase were assayed as per the below mentioned methodology.

\section{Superoxide dismutase (EC 1.15.1.1)}

Superoxide dismutase was assayed by measuring its ability to inhibit the photochemical reduction of nitroblue tetrazolium, adopting the method of Giannopolities and Ries (1977). The reaction mixture $(3 \mathrm{ml})$ contained $50 \mathrm{mM}$ phosphate buffer (pH 7.8), $14 \mathrm{mM}$ L-methionine, $10 \mu \mathrm{M}$ nitroblue tetrazolium, $3 \mu \mathrm{M}$ riboflavin, 0.1 $\mathrm{mM}$ EDTA and $0.1 \mathrm{ml}$ of enzyme extract. Riboflavin was added in the end. The tubes were properly shaken and placed $30 \mathrm{~cm}$ below light source consisting of two $15 \mathrm{~W}$ fluorescent lamps (Phillips, India). The absorbance was recorded at $560 \mathrm{~nm}$. One enzyme unit was defined as the amount of enzyme which could cause 50 per cent inhibition of the photochemical reaction.

\section{Catalase (EC 1.11.1.6)}

Catalase activity was determined by the procedure of Sinha (1972). The reaction mixture $(1.0 \mathrm{ml})$ consisted of $0.5 \mathrm{ml}$ of phosphate buffer $(\mathrm{pH} 7.0), 0.4 \mathrm{ml}$ of $0.2 \mathrm{M}$ hydrogen peroxide and $0.1 \mathrm{ml}$ of properly diluted enzyme extract. After incubating at $37^{\circ} \mathrm{C}$ for $3 \mathrm{~min}$, the reaction was terminated by adding $3 \mathrm{ml}$ mixture of $5 \%(w / v)$ potassium dichromate and glacial acetic acid $(1: 3 v / v)$ to the reaction mixture. The tubes were heated in 
boiling water bath for $10 \mathrm{~min}$. Absorbance of test and control was measured at $570 \mathrm{~nm}$. One unit of enzyme activity is defined as the amount of enzyme which catalyzed the oxidation of $1 \mu$ mole $\mathrm{H}_{2} \mathrm{O}_{2}$ per minute under assay conditions.

\section{Peroxidase (EC 1.11.1.7)}

The enzyme activity was estimated by the method of Shannon et al., (1966). The reaction mixture $(2.75 \mathrm{ml})$ contained $2.5 \mathrm{ml}$ of $50 \mathrm{mM}$ phosphate buffer $(\mathrm{pH}$ 6.5), $0.1 \mathrm{ml}$ of $0.5 \%$ hydrogen peroxide, and $0.1 \mathrm{ml}$ of $0.2 \% \mathrm{O}$ dianisidine and $0.05 \mathrm{ml}$ of enzyme extract. The reaction was initiated by the addition of $0.1 \mathrm{ml}$ of $\mathrm{H}_{2} \mathrm{O}_{2}$. The assay mixture without $\mathrm{H}_{2} \mathrm{O}_{2}$ served as blank. Change in absorbance was followed at $430 \mathrm{~nm}$ for $3 \mathrm{~min}$. One unit of peroxidase was defined as amount of enzyme required to cause change in 0.1 O.D. per minute under assay condition.

\section{Ascorbate peroxidase (EC 1.11.1.11)}

The enzyme activity was determined following the oxidation of ascorbic acid (Nakano and Asada, 1981). The reaction mixture contained $2.5 \mathrm{ml}$ of $100 \mathrm{mM}$

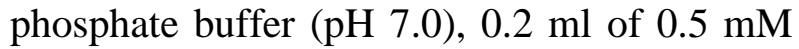
ascorbate, $0.2 \mathrm{ml}$ of $0.1 \mathrm{mM} \mathrm{H} \mathrm{H}_{2}$ and $0.1 \mathrm{ml}$ of enzyme extract. The reaction was initiated by the addition of $\mathrm{H}_{2} \mathrm{O}_{2}$. The decrease in absorbance at $290 \mathrm{~nm}$ was recorded spectrophotometrically which corresponded to oxidation of ascorbic acid. The enzyme activity was calculated using the molar extinction coefficient of $2.8 \mathrm{mM}^{-1} \mathrm{~cm}^{-1}$ for ascorbic acid. One enzyme unit was defined as amount of enzyme required to oxidize 1 nmole of ascorbic acid per min at $290 \mathrm{~nm}$.

\section{Glutathione reductase (EC 1.6.4.2)}

Method of Halliwell and Foyer (1978) was followed for measuring the enzyme activity.
The reaction mixture consisted of $2.7 \mathrm{ml}$ of $0.1 \mathrm{M}$ phosphate buffer ( $\mathrm{pH} 7.5$ ), $0.1 \mathrm{ml}$ of 5 $\mathrm{mM}$ oxidized glutathione $(\mathrm{GSSH}), 0.1 \mathrm{ml}$ of $3.5 \mathrm{mM}$ NADPH and $0.1 \mathrm{ml}$ enzyme extract in final volume of $3 \mathrm{ml}$. The decrease in absorbance at $340 \mathrm{~nm}$ due to oxidation of NADPH was monitored. Non-enzymatic oxidation of NADPH was recorded and subtracted from it. An extinction coefficient of $6.22 \mathrm{mM}^{-1} \mathrm{~cm}^{-1}$ for NADPH was used to calculate the amount of NADPH oxidized which corresponded to GR activity. One enzyme unit was defined as amount of enzyme required to oxidize 1.0 nmole of $\mathrm{NADPH}$ oxidized per min.

\section{Results and Discussion}

\section{Superoxide Dismutase (SOD)}

Results depicted in Fig. 1(a) and Fig. 1(b) show the SOD activity in $2^{\text {nd }}$ and $6^{\text {th }}$ healthy leaves of resistant and susceptible cotton genotypes respectively. The activity of SOD in $2^{\text {nd }}$ leaf before infection (50 DAS) was maximum in $G$. arboreum genotypes (41.1446.66 units $\mathrm{mg}^{-1}$ protein) followed by $G$. hirsutum resistant genotypes (26.58-36.76 units $\mathrm{mg}^{-1}$ protein) and minimum in $G$. hirsutum susceptible genotypes (18.09-20.41 units $\mathrm{mg}^{-1}$ protein). $6^{\text {th }}$ leaf had maximum activity in $G$. arboreum genotypes (52.2156.90 units $\mathrm{mg}^{-1}$ protein) followed by $G$. hirsutum resistant genotypes (29.75-39.18 units $\mathrm{mg}^{-1}$ protein) and minimum in $G$. hirsutum susceptible genotypes (20.85-23.86 units $\mathrm{mg}^{-1}$ protein). SOD activity was higher in resistant genotypes than susceptible genotypes. $6^{\text {th }}$ leaf had more activity than $2^{\text {nd }}$ leaf in all the genotypes. All the genotypes not differ significantly in SOD activity.

Results depicted in Fig. 1(c) show the effect of pests infection on SOD activity in $2^{\text {nd }}$ leaf of resistant and susceptible cotton genotypes and Fig. 1(d) shows the effect of pests infection on 
SOD activity in $6^{\text {th }}$ leaf of resistant and susceptible cotton genotypes. After infection increase in SOD activity was observed in $G$. hirsutum genotypes. In $2^{\text {nd }}$ leaf, at 60 DAS, increase in SOD activity was 30.56- $67.51 \%$ in resistant genotypes and 26.34- $43.32 \%$ in susceptible genotypes whereas at 68 DAS, more increase in SOD activity was observed and increase was $44.52-83.02 \%$ in resistant genotypes and $39.06-65.27 \%$ in susceptible genotypes. In $6^{\text {th }}$ leaf increase was $27.44-$ $53.22 \%$ in resistant genotypes and 29.09$34.31 \%$ in susceptible genotypes at 60 DAS and 68 DAS stage had 41.58- $73.16 \%$ increase in resistant genotypes and $39.79-54.45 \%$ in susceptible genotypes. Significant increase was observed in all the genotypes.

\section{Catalase (CAT)}

Results depicted in Fig. 2(a) and Fig. 2(b) show the CAT activity in $2^{\text {nd }}$ and $6^{\text {th }}$ healthy leaves of resistant and susceptible cotton genotypes respectively. The activity of catalase followed similar trend as SOD activity in both $2^{\text {nd }}$ and $6^{\text {th }}$ leaves before infection. Maximum activity of CAT in $2^{\text {nd }}$ leaf was in G. arboreum genotypes (366.65422.98 units $\mathrm{mg}^{-1}$ protein) followed by $G$. hirsutum resistant genotypes (267.65-366.77 units $\mathrm{mg}^{-1}$ protein) and minimum in $G$. hirsutum susceptible genotypes (226.13275.29 units $\mathrm{mg}^{-1}$ protein). In $6^{\text {th }}$ leaf, $G$. arboreum genotypes had maximum activity (505.43-535.11 units $\mathrm{mg}^{-1}$ protein) followed by G. hirsutum resistant genotypes (424.99456.69 units $\mathrm{mg}^{-1}$ protein) and minimum in $G$. hirsutum susceptible genotypes (258.82278.60 units $\mathrm{mg}^{-1}$ protein). $6^{\text {th }}$ leaf had more activity than $2^{\text {nd }}$ leaf in all the genotypes. All the genotypes differ significantly in CAT activity.

Results depicted in Fig. 2(c) show the effect of pests infection on CAT activity in $2^{\text {nd }}$ leaf of resistant and susceptible cotton genotypes and
Fig. 2(d) shows the effect of pests infection on CAT activity in $6^{\text {th }}$ leaf of resistant and susceptible cotton genotypes.

After infection increase in CAT activity was observed in G. hirsutum genotypes. In $2^{\text {nd }}$ leaf, at 60 DAS, increase was $34.78-77.83 \%$ in resistant genotypes and $2.92-16.89 \%$ in susceptible genotypes whereas at 68 DAS, more increase in CAT activity was observed and increase was $78.04-155.74 \%$ in resistant genotypes and $45.84-81.69 \%$ in susceptible genotypes. In $6^{\text {th }}$ leaf increase was 28.10 $39.67 \%$ in resistant genotypes and 6.00$15.37 \%$ in susceptible genotypes at 60 DAS and at 68 DAS stage increase was 46.73$58.97 \%$ in resistant genotypes and 43.87$57.86 \%$ in susceptible genotypes. Significant increase was observed in all the genotypes.

\section{Peroxidase (POX)}

Results depicted in Fig. 3(a) and Fig. 3(b) show the POX activity in $2^{\text {nd }}$ and $6^{\text {th }}$ healthy leaves of resistant and susceptible cotton genotypes respectively. In $2^{\text {nd }}$ leaf POX activity was maximum in $G$. arboreum genotypes (44.91-47.16 units $\mathrm{mg}^{-1}$ protein) followed by $G$. hirsutum resistant genotypes (23.34-26.46 units $\mathrm{mg}^{-1}$ protein) and minimum in G. hirsutum susceptible genotypes (12.1316.96). In $6^{\text {th }}$ leaf, G. arboreum genotypes had maximum activity (51.82-54.43 units $\mathrm{mg}^{-1}$ protein) followed by $G$. hirsutum resistant genotypes (22.19-28.31 units $\mathrm{mg}^{-1}$ protein) and minimum in $G$. hirsutum susceptible genotypes (14.15-17.81 units $\mathrm{mg}^{-1}$ protein). POX activity was higher in resistant genotypes than susceptible genotypes. $6^{\text {th }}$ leaf had more activity than $2^{\text {nd }}$ leaf in all the genotypes. All the genotypes not differ significantly in POX activity.

Results depicted in Fig. 3(c) show the effect of pests infection on POX activity in $2^{\text {nd }}$ leaf of resistant and susceptible cotton genotypes and 
Fig. 3(d) shows the effect of pests infection on POX activity in $6^{\text {th }}$ leaf of resistant and susceptible cotton genotypes. After infection increase in POX activity was observed in $G$. hirsutum genotypes. In $2^{\text {nd }}$ leaf, at 60 DAS, increase in POX activity was $55.79-139.59 \%$ in resistant genotypes and 26.11-43.59\% in susceptible genotypes whereas at 68 DAS stage more increase in POX activity was observed and increase was $130.85-140.13 \%$ in resistant genotypes and $44.85-74.71 \%$ in susceptible genotypes in $2^{\text {nd }}$ leaf.

In 6th leaf increase was 52-58.82\% in resistant genotypes and $19.83-24.60 \%$ in susceptible genotypes at 60 DAS and at 68 DAS stage, increase was $156.71-167.54 \%$ in resistant genotypes and $55.01-84.64 \%$ in susceptible genotypes. Significant increase was observed in all the genotypes.

\section{Ascorbate Peroxidase (APX)}

Results depicted in Fig. 4(a) and Fig. 4(b) show the APX activity in $2^{\text {nd }}$ and $6^{\text {th }}$ healthy leaves of cotton genotypes respectively. In $2^{\text {nd }}$ leaf, APX activity was maximum in $G$. arboreum genotypes (318.60-327.68 units $\mathrm{mg}^{-}$ 1 protein) followed by $G$. hirsutum resistant genotypes (201.42-223.60 units $\mathrm{mg}^{-1}$ protein) and minimum in $G$. hirsutum susceptible genotypes (134.82-147.74 units $\mathrm{mg}^{-1}$ protein). $6^{\text {th }}$ leaf had maximum activity in $G$. arboreum genotypes (377.62-401.42 units $\mathrm{mg}^{-1}$ protein) followed by $G$. hirsutum resistant genotypes (231.52-275.46 units $\mathrm{mg}^{-1}$ protein) and minimum in $G$. hirsutum susceptible genotypes (175.28-215.28 units $\mathrm{mg}^{-1}$ protein). APX activity was higher in resistant genotypes than susceptible genotypes. $6^{\text {th }}$ leaf had more activity than $2^{\text {nd }}$ leaf in all the genotypes. All the genotypes not differ significantly in APX activity. Results depicted in Fig. 4(c) show the effect of pests infection on APX activity in $2^{\text {nd }}$ leaf of resistant and susceptible cotton genotypes and Fig. 4(d) shows the effect of pests infection on APX activity in $6^{\text {th }}$ leaf of resistant and susceptible cotton genotypes. No visible symptoms of infection were observed in G. arboreum genotypes. After infection, increase in APX activity was observed $G$. hirsutum genotypes. In $2^{\text {nd }}$ leaf, after pests infection at 60 DAS, increase in APX activity was $27.12-45.01 \%$ in resistant genotypes and $23.50-38.49 \%$ in susceptible genotypes whereas at 68 DAS stage more increase in APX activity was observed and increase was $104.77-134.60 \%$ in resistant genotypes and $84.09-95.34 \%$ in susceptible genotypes. In $6^{\text {th }}$ leaf increase was $73.67-109.31 \%$ in resistant genotypes and $32.41-63.48 \%$ in susceptible genotypes at 60 DAS and at 68 DAS, increase in APX activity was $106.65-136.43 \%$ in resistant genotypes and 96.06-115.05\% in susceptible genotypes. Significant increase in APX activity was observed in $2^{\text {nd }}$ leaf at 68 DAS, in $6^{\text {th }}$ leaf at 60 DAS \& 68 DAS stages wheras non-significant increase in APX activity was observed in $2^{\text {nd }}$ leaf at 68 DAS.

\section{Glutathione Reductase (GR)}

Results depicted in Fig. 5(a) and Fig. 5(b) show the GR activity in $2^{\text {nd }}$ and $6^{\text {th }}$ healthy leaves of resistant and susceptible cotton genotypes respectively. In $2^{\text {nd }}$ leaf GR activity was maximum in $G$. arboreum genotypes (204.34-214.35 units $\mathrm{mg}^{-1}$ protein) followed by $G$. hirsutum resistant genotypes (104.56141.67 units $\mathrm{mg}^{-1}$ protein) and minimum in $G$. hirsutum susceptible genotypes (68.67-83.04 units $\mathrm{mg}^{-1}$ protein). In $6^{\text {th }}$ leaf, G. arboreum genotypes had maximum activity (222.35230.41 units $\mathrm{mg}^{-1}$ protein) followed by $G$. hirsutum resistant genotypes (133.68-146.39 units $\mathrm{mg}^{-1}$ protein) and minimum in $G$. hirsutum susceptible genotypes (86.73-88.77 units $\mathrm{mg}^{-1}$ protein). GR activity was higher in resistant genotypes than susceptible genotypes. $6^{\text {th }}$ leaf had more activity than $2^{\text {nd }}$ leaf in all the genotypes. All the genotypes not differ significantly in GR activity. 
(a)

(b)
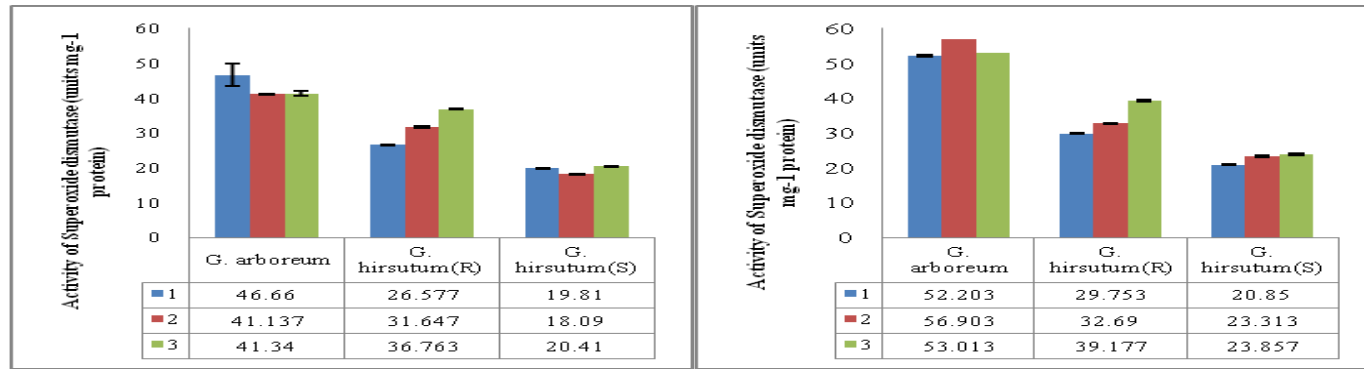

Fig. 1: Superoxide dismutase (units $\mathrm{mg}^{-1}$ protein) in (a) $2^{\text {nd }}$ and (b) $6^{\text {th }}$ healthy leaves of resistant and susceptible cotton genotypes

$\begin{array}{llll}\text { In } \text { G. arboreum } & \text { 1=HD 418 } & \text { 2=HD503 } & \text { 3=HD432 } \\ \text { In G. hirsutum (R) } & \text { 1=H1464 } & \text { 2=H1465 } & \text { 3=H1098 } \\ \text { In G. hirsutum (S) } & \text { 1=H1463 } & \text { 2=H1454 } & \text { 3=H1439 } \\ \text { CD at 5\%: (a) Genotypes=3.39 } & & & \text { (b) Genotypes=0.50 }\end{array}$

(c)

(d)

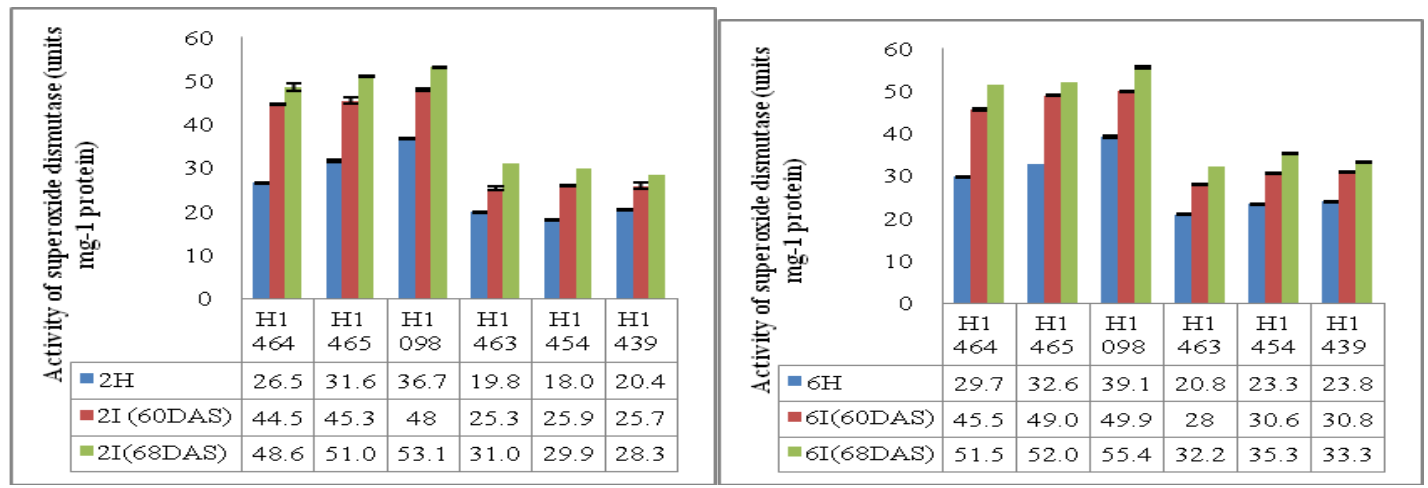

Fig. 1: Effect of pests infection on Superoxide dismutase (units $\mathrm{mg}^{-1}$ protein) in (c) $2^{\text {nd }}$ and (d) $6^{\text {th }}$ leaves of resistant and susceptible cotton genotypes

$2 \mathrm{H}=2^{\text {nd }}$ healthy leaf $2 \mathrm{I}=2^{\text {nd }}$ Infected leaf $\quad 6 \mathrm{H}=6^{\text {th }}$ Healthy leaf $\quad 6 \mathrm{I}=6^{\text {th }} \quad$ Infected leaf
(c) H, I (60DAS)
H, I (68DAS)
(d) H, I (60DAS) (68DAS)

$\mathrm{H}, \quad \mathrm{I}$ 
(a)

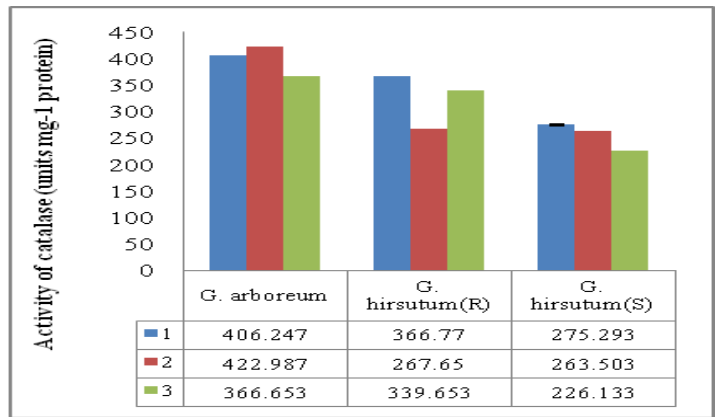

(b)

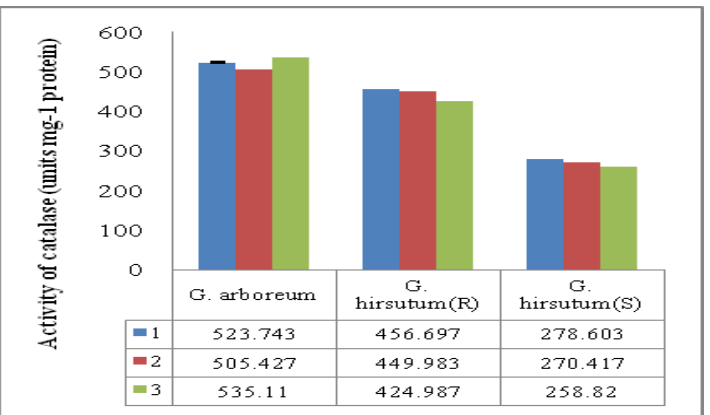

Fig. 2: Catalase activity (units $\mathrm{mg}^{-1}$ protein) in (a) $2^{\text {nd }}$ and (b) $6^{\text {th }}$ healthy leaves of resistant and susceptible cotton genotypes

In $G$. arboreum

In $G$. hirsutum (R)

In G. hirsutum (S)

$\mathrm{CD}$ at $5 \%$ : (a) Genotypes $=1.25$

$$
\begin{aligned}
& \text { 1=HD } 418 \\
& \text { 1=H1464 } \\
& \text { 1=H1463 }
\end{aligned}
$$

(c)

$\begin{array}{ll}2=H D 503 & 3=H D 432 \\ 2=H 1465 & 3=H 1098 \\ 2=H 1454 & 3=H 1439\end{array}$

(b) Genotypes $=1.05$

(d)

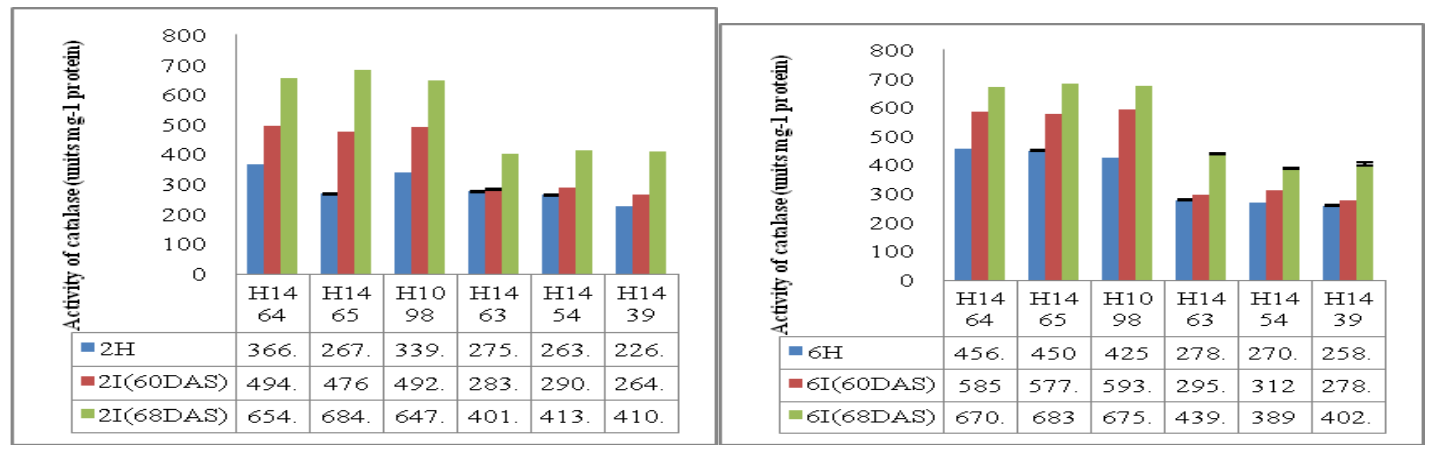

Fig. 2: Effect of pests infection on Catalase activity (units $\mathrm{mg}^{-1}$ protein) in (c) $2^{\text {nd }}$ and (d) $6^{\text {th }}$ leaves of resistant and susceptible cotton genotypes

$2 \mathrm{H}=2^{\text {nd }}$ healthy leaf $6 \mathrm{I}=6^{\text {th }}$ Infected leaf (c) H, I (60DAS)

(68DAS)

Genotypes $=1.02$

Treatment $=0.59$

Genotypes $=0.71$

Treatment $=0.41$
$2 \mathrm{I}=2^{\text {nd }}$ Infected leaf

H, I (68DAS)

(d) H, I (60DAS)

$\mathrm{H}$,

Genotypes $=3.73$

Treatment $=2.15$

Genotypes $\times$ Treatment $=1.44$ Genotypes $\times$ Treatment $=1.01$ Genotypes $\times$ Treatment $=0.94$ Genotypes $\times$ Treatment $=5.28$ 
(a)

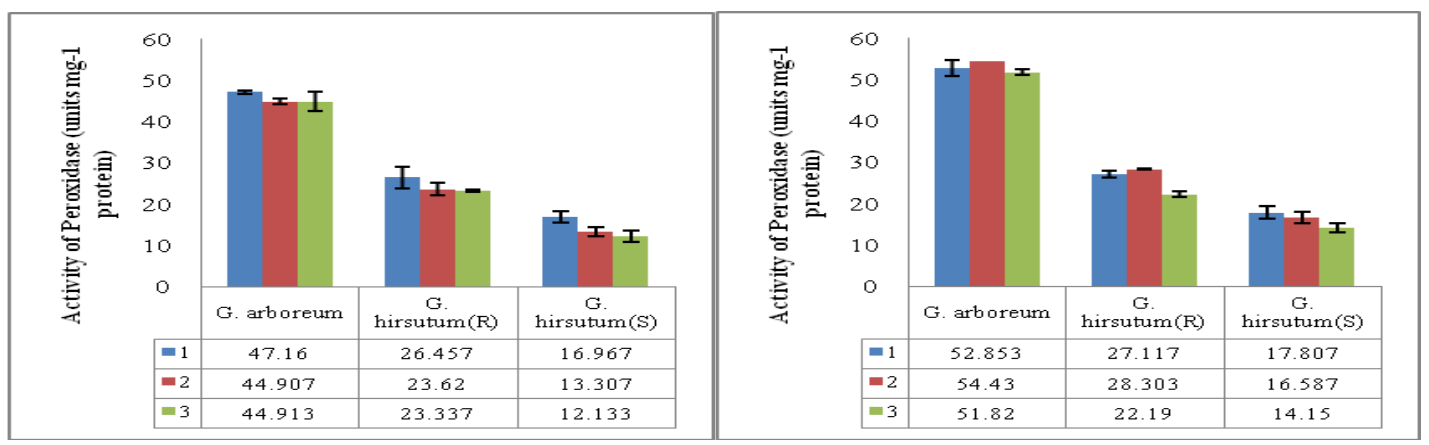

Fig. 3: Peroxidase activity (units mg-1 protein) in (a) $2^{\text {nd }}$ and (b) $6^{\text {th }}$ healthy leaves of resistant and susceptible cotton genotypes

In $G$. arboreum

In $G$. $\operatorname{hirsutum}(\mathrm{R})$

In $G$. hirsutum $(\mathrm{S})$

$\mathrm{CD}$ at $5 \%$ :

(a) Genotypes $=4.46$

$\begin{array}{lr}2=\mathrm{HD} 503 & 3=\mathrm{HD} 432 \\ 2=\mathrm{H} 1465 & 3=\mathrm{H} 1098 \\ 2=\mathrm{H} 1454 & 3=\mathrm{H} 1439\end{array}$

(b) Genotypes $=3.25$

(d)

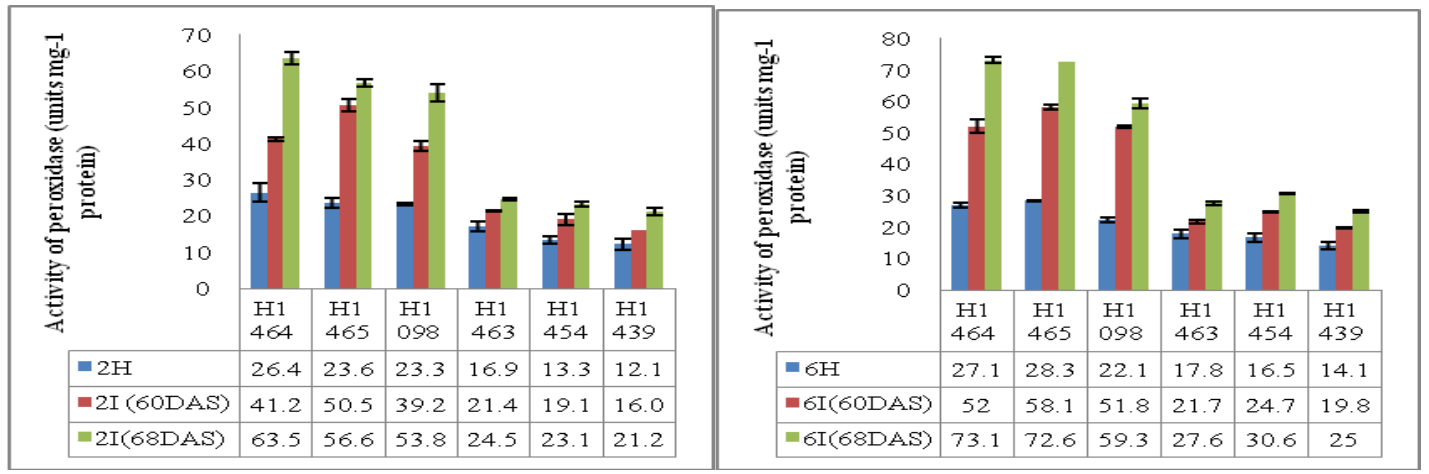

Fig. 3: Effect of pests infection on Peroxidase activity (units $\mathrm{mg}^{-1}$ protein) in (c) $2^{\text {nd }}$ and (d) $6^{\text {th }}$ leaves of resistant and susceptible cotton genotypes

$2 \mathrm{H}=2^{\text {nd }}$ healthy leaf $\quad 2 \mathrm{I}=2^{\text {nd }}$ Infected leaf $\quad 6 \mathrm{H}=6^{\text {th }}$ Healthy leaf $6 \mathrm{I}=6^{\text {th }}$ Infected leaf
(c) H, I (60DAS)
H, I (68DAS)
(d) H, I (60DAS)
$\mathrm{H}, \quad \mathrm{I}$ (68DAS)

$\begin{array}{lccc}\text { Genotypes }=2.72 & \text { Genotypes }=3.04 & \text { Genotypes }=2.09 & \text { Genotypes }=1.96 \\ \text { Treatment }=1.57 & \text { Treatment }=1.76 & \text { Treatment }=1.21 & \text { Treatment }=1.13 \\ \text { Genotypes } \times \text { Treatment }=3.84 \text { Genotypes } \times \text { Treatment }=4.30 & \text { Genotypes } \times \text { Treatment=2.96 Genotypes } \times \text { Treatment }=2.7\end{array}$


(a)

(b)

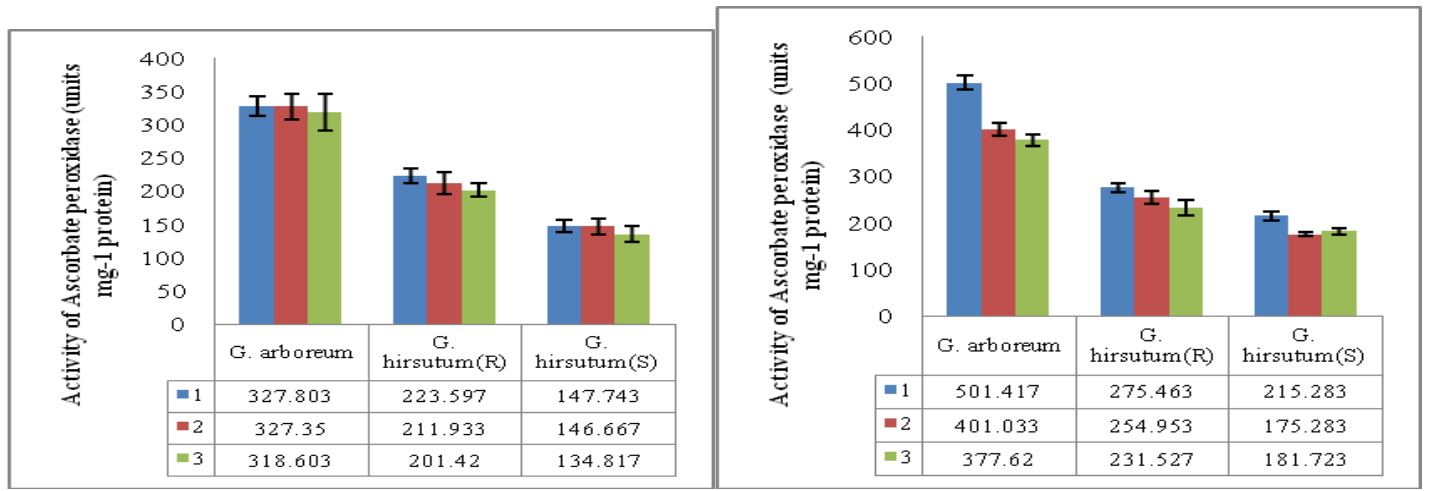

Fig. 4: Ascorbate peroxidase activity (units $\mathrm{mg}^{-1}$ protein) in (a) $2^{\text {nd }}$ and (b) $6^{\text {th }}$ healthy leaves of resistant and susceptible cotton genotypes

$\begin{array}{llll}\text { In } G . \text { arboreum } & 1=\mathrm{HD} 418 & 2=\mathrm{HD} 503 & 3=\mathrm{HD} 432 \\ \text { In } G . \operatorname{hirsutum}(\mathrm{R}) & 1=\mathrm{H} 1464 & 2=\mathrm{H} 1465 & 3=\mathrm{H} 1098 \\ \text { In } G . \operatorname{hirsutum}(\mathrm{S}) & 1=\mathrm{H} 1463 & 2=\mathrm{H} 1454 & 3=\mathrm{H} 1439\end{array}$

$\mathrm{CD}$ at 5\%: (a) Genotypes $=15.82$

(b) Genotypes=11.91

(c)

(d)

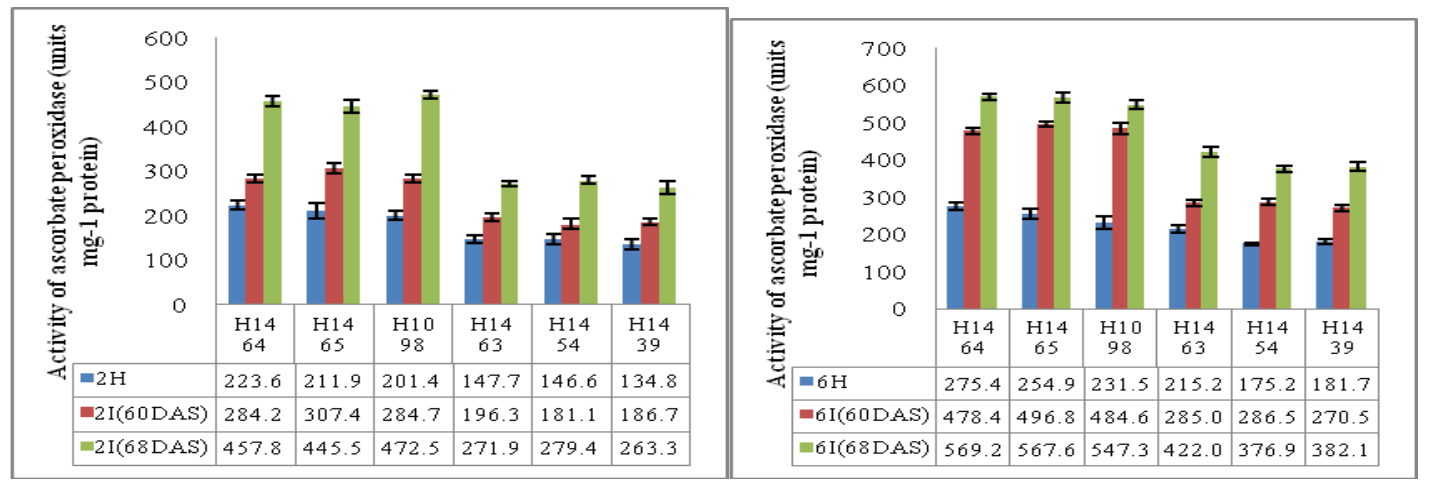

Fig. 4: Effect of pests infection on Ascorbate peroxidase activity (units $\mathrm{mg}^{-1}$ protein) in (c) $2^{\text {nd }}$ and (d) $6^{\text {th }}$ leaves of resistant and susceptible cotton genotypes

$2 \mathrm{H}=2^{\text {nd }}$ healthy leaf

2I $=2^{\text {nd }}$ Infected leaf

$6 \mathrm{H}=6^{\text {th }}$ Healthy leaf

$6 \mathrm{I}=6^{\text {th }}$ Infected leaf

(c) H, I (60DAS)

H, I (68DAS)

(d) H, I (60DAS)

$\mathrm{H}, \mathrm{I}(68 \mathrm{DAS})$

Genotypes $=22.9$

Genotypes $=26.69$

Genotypes $=30.77$

Genotypes $=22.93$

Treatment $=13.25$

Treatment $=15.41$

Treatment $=17.77$

Treatment $=13.24$

Genotypes $\times$ Treatment $=$ N/AGenotypes $\times$ Treatment $=37.76$

Genotypes $\times$ Treatment $=43.52$ Genotypes $\times$

Treatment $=32.43$ 
(a)

(b)

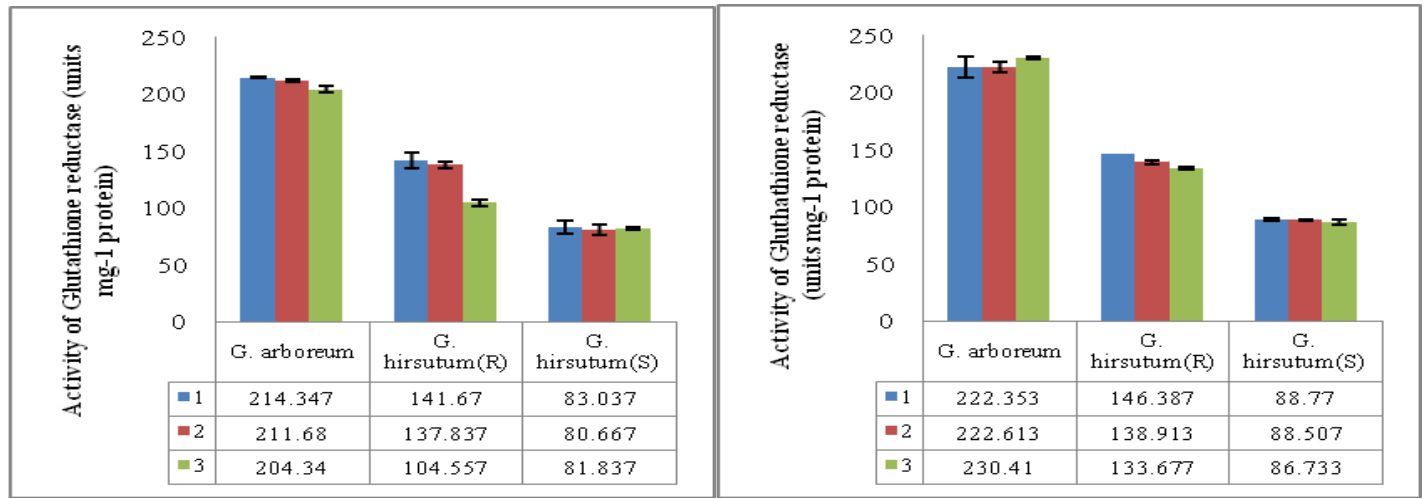

Fig. 5: Glutathione reducatse activity (units $\mathrm{mg}^{-1}$ protein) in (a) $2^{\text {nd }}$ and (b) $6^{\text {th }}$ healthy leaves of resistant and susceptible cotton genotypes

In $G$. arboreum

$$
1=\mathrm{HD} 418
$$

$2=\mathrm{HD} 503$

$3=\mathrm{HD} 432$

In G. hirsutum (R)

$1=\mathrm{H} 1464$

$2=\mathrm{H} 1465$

$3=\mathrm{H} 1098$

In $G$. hirsutum (S)

$1=\mathrm{H} 1463$

$2=\mathrm{H} 1454$

$3=\mathrm{H} 1439$

CD at 5\%: (a) Genotypes $=11.03$

(b) Genotypes=10.49

(c)

(d)

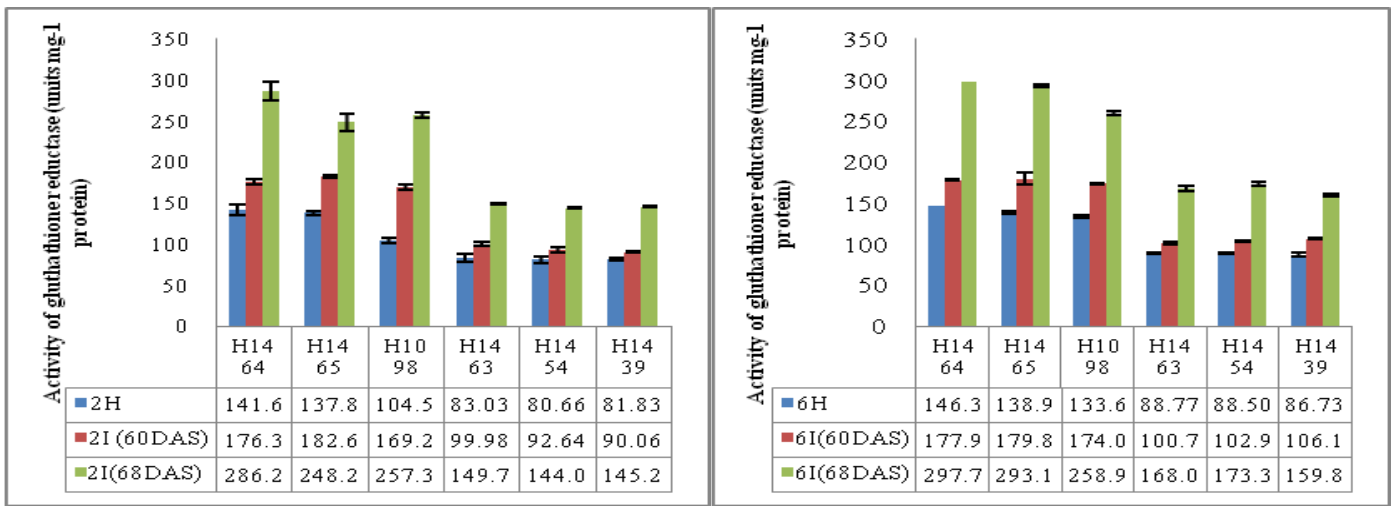

Fig. 5: Effect of pests infection on Glutathione reducatse activity (units $\mathrm{mg}^{-1}$ protein) in (c) $2^{\text {nd }}$ and (d) $6^{\text {th }}$ leaves of resistant and susceptible cotton genotypes

$2 \mathrm{H}=2^{\text {nd }}$ Healthy leaf (c) H, I (60DAS)

Genotypes $=7.42$

Treatment $=4.28$

Genotypes $\times$ Treatment=10.49
$2 \mathrm{I}=2^{\text {nd }}$ Infected leaf
$\mathrm{H}, \mathrm{I}(68 \mathrm{DAS})$

Genotypes $=14.90$

Treatment $=8.60$

Genotypes $\times$ Treatment $=21.07$
$6 \mathrm{H}=6^{\text {th }}$ Healthy leaf (d) H, I (60DAS)

Genotypes $=4.96$

Treatment $=2.87$
$\mathrm{H}, \mathrm{I}(68 \mathrm{DAS})$

Genotypes $=3.75$

Treatment $=2.17$
$6 \mathrm{I}=6^{\text {th }}$ Infected leaf

Genotypes $\times$ Treatment $=7.02$ Genotypes $\times$ Treatment $=5.31$ 
Results depicted in Fig. 5(c) show the effect of pests infection on GR activity in $2^{\text {nd }}$ leaf of resistant and susceptible cotton genotypes and Fig. 5(d) shows the effect of pests infection on GR activity in $6^{\text {th }}$ leaf of resistant and susceptible cotton genotypes. No visible symptoms of infection were observed in $G$. arboreum genotypes. After infection increase in GR activity was observed in G. hirsutum genotypes. In $2^{\text {nd }}$ leaf, at 60 DAS, increase in GR activity was $24.47-61.84 \%$ in resistant genotypes and $10.05-20.41 \%$ in susceptible genotypes whereas at 68 DAS stage, more increase in GR activity was observed and increase was $68.11-146.10 \%$ in resistant genotypes and $77.50-68.32 \%$ in susceptible genotypes. In $6^{\text {th }}$ leaf increase was 21.57 $30.18 .00 \%$ in resistant genotypes and 13.49$22.39 \%$ in susceptible genotypes at 60 DAS and at 68 DAS stage increase was 93.72$111.03 \%$ in resistant genotypes and 84.35$95.82 \%$ in susceptible genotypes. Significant increase was observed in all the genotypes.

The activity increased in all the genotypes but the increase was more in resistant genotypes as compared to susceptible genotypes and all the genotypes differ significantly in GR activity.

Among the enzymes involved in antioxidative defense system, superoxide dismutase (SOD) is the first enzyme in ROS detoxifying process. It converts. $\mathrm{O}_{2}^{-}$to $\mathrm{H}_{2} \mathrm{O}_{2}$ and $\mathrm{H}_{2} \mathrm{O}_{2}$ so produced is scavenged to $\mathrm{O}_{2}$ and water by the enzymes such as APX, POX and CAT. In present study, SOD activity increased on pests infection and increase was more in resistant genotypes than susceptible genotypes and in all genotypes $6^{\text {th }}$ leaf showed enhanced activity than $2^{\text {nd }}$ leaf (fig. 1c \& 1d). Similarly results were obtained in cotton plants infested by $S$. litura showed induced SOD activity (Usha Rani and Pratyusha, 2013). Similar increase was also observed in the castor and lima bean plants infested by herbivory
(Maffei et al., 2006). The SOD activity was also shown to increase in strawberry leaves infected by Mycosphaerella fragariae but the SOD activity for the resistant cultivars was higher than for the susceptible ones (EhsaniMoghaddam et al., 2006).

Catalase (CAT) activity increased in both $2^{\text {nd }}$ $\& 6^{\text {th }}$ leaves after pests infection in both resistant and susceptible genotypes (fig. 2 a \& 2b). Enhanced CAT activity was observed in resistant genotypes than susceptible genotypes at both 60 DAS and 68 DAS stage in both $2^{\text {nd }} \& 6^{\text {th }}$ leaves on pests infection (fig. 2c \& 2d). Similarly, a 23 fold increase in CAT activity was observed in maize plants inoculated with $P$. indica as compared to noninoculated plants (Kumar et al., 2009). Maximum increase in CAT activity after cotton leaf curl burewala virus inoculation was in resistant genotypes as followed by susceptible genotypes as compared to their non-inoculated plants (Siddique et al., 2014). Similar increases in foliar CAT activity were also observed in Algerian-susceptible but not in Algerian-Resistant barley (Hordeum vulgare L.) leaves inoculated with Blumeria graminis (Vanacker et al., 1998). Cotton plants infested by $S$. litura showed induced the CAT activity (Usha Rani and Pratyusha, 2013).

Peroxidases (POX) are a group of enzymes that detoxify $\mathrm{H}_{2} \mathrm{O}_{2}$ by utilizing an electron donating substrate for the oxidation of $\mathrm{H}_{2} \mathrm{O}_{2}$ (Dionisio-sese and Tobita, 1998). POX activity increased in $2^{\text {nd }}$ and $6^{\text {th }}$ leaves of all the cotton genotypes on pests infection and the increase was higher in resistant genotypes as compared to susceptible genotypes (fig 3c $\& 3 d)$. Similar to our results, many scientists have reported higher peroxidase activity in resistant cultivars of various crops infected with different types of pathogens. Cotton plants infested by $S$. litura induced the CAT activity (Usha Rani and Pratyusha, 2013). 
Infection with plant pathogens led to an induction in POX activity in plant tissues and a greater increase was recorded in resistant plants compared to the susceptible ones (Mydlarz and Harvell, 2006). Similar increase in POX activity has been reported in tomato and bell pepper infected with tobacco mosaic virus and tomato mosaic tobamovirus (Madhusudhan et al., 2009); cucumber mosaic virus and zucchini yellow mosaic virus-infected Cucumis sativus and Cucurbita pepo plants (Bauer, 2000); tobacco mosaic virus infected tobacco plants (Kiraly et al., 2002); tomato yellow leaf curl virus infected tomato plants (Dieng et al., 2011) and a number of resistant interactions involving several plant patho systems.

Ascorbate peroxidase, a hydrogen peroxide scavenging enzyme is a major enzyme responsible for elimination of hydrogen peroxide. The results of present study showed that APX activity was substantially higher in resistant genotypes as compared to susceptible genotypes in healthy leaves (fig. $4 a \& 4 b)$.

The APX activity increased in all genotypes infected by pests and increase was higher in resistant genotypes at both 60 DAS and 68 DAS stages (fig. 4c \& 4d). Similar observations have been reported for APX activity in soybean and cotton foliage after herbivory attack by $H$. zea ( $\mathrm{Bi}$ and Felton, 1995; Bi et al., 1997). Lukasik et al., (2012) observed more induction in APX activity in less susceptible cultivars than more susceptible cultivars in triticale after $24 \mathrm{hrs}$ of cereal aphid infestation and there prolonged feeding (after 48 and 72 hrs) caused the strongest induction of APX. Similarly, a rapid increase was observed in more resistant cultivar of chrysanthemum infested by Macrosiphoniella sanbourni (Gillete) indicated that the enzyme is involved in early responses to aphid attack (He et al., 2011).
Glutathione reductase (GR) is another specific and important enzyme of ascorbateglutathione cycle and plays a crucial role in affording protection against oxidative damage in many plants (Foyer et al., 1991) by maintaining endogenous pool of reduced glutathione (GSH). Our results showed that GR activity increased in both $2^{\text {nd }}$ and $6^{\text {th }}$ leaves of both resistant and susceptible cotton genotypes on pests infection and increase was more pronounced in resistant genotypes than susceptible genotypes (fig. 5c \& 5d). Similarly, Hernández et al., (2001) found that the GR activity in the resistant plants was higher than in the susceptible plants of apricot after inoculation with the Plum pox virus. Debona et al., (2012) observed that wheat varieties inoculated with Pyricularia oryzae for $96 \mathrm{hr}$ at vegetative stage showed increase in GR activity in partially resistant plants (BRS 229) and no significant change in susceptible (BR 18) plants.

To summarize results presented here show that leaves of resistant genotypes had less production of ROS, higher level of ascorbic acid and higher activities of POX, APX, CAT, SOD and GR as compared to susceptible genotypes of cotton. Suggesting that these components of antioxidative defence system play important role in providing pest resistance in cotton genotypes studied here.

The maximum increase in activities of enzymes viz. CAT, POX, SOD, APX and GR were observed in $6^{\text {th }}$ leaves after pests infection. Maximum increase in antioxidative enzymes was observed in HD418 of $G$. arboreum, $\mathrm{H} 1098$ of $G$. hirsutum (R) and H1454 genotype of $G$. hirsutum (S). The results indicated that biochemical parameters studied in the present investigation play important role in providing resistance to sucking pests infection in cotton genotypes studied in the present investigation. 


\section{Acknowledgments}

The authors thank Chaudhary Charan Singh Haryana Agricultural University, Hisar, Haryana and Indian Council of Agricultural Research, New Delhi for providing the necessary funding and facilities for carrying out this research.

\section{References}

Agrawal, A.A., Fishbein, M., Jetter, R., Salminen, J.P., Goldstein, J.B., Freitag, A.E. and Sparks, J.P. 2009. Phylogenetic ecology of leaf surface traits in the milkweeds (Asclepias spp.): chemistry, ecophysiology, and insect behavior. New Phytol. 183(3): 849-67.

Akhtar, K.P., Haidar, S., Khan, M.K.R., Ahmad, M., Sarwar, N., Murtaza, M.A. and Aslam, M. 2010. Evaluation of Gossypium species for resistance to cotton leaf curl Burewala virus. Annual Appl. Biol. 157:135-147.

Akhtar, K.P., Ullah, R., Khan, I.A., Saeed, M., Sarwar, N. and Mansoor, S. 2013. First symptomatic evidence of infection of Gossypium arboreum with cotton leaf curl Burewala virus through grafting. Intrn. J. Agric. Biol. 15:157-160.

Bauer, R. 2000. Role of reactive oxygen species and antioxidant enzymes in systemic virus infection of plants. J. Phytopathol. 148: 297-302.

Bi, J.L. and Felton, G.W. 1995. Foliar oxidative stress and insect herbivory: Primary compounds, secondary metabolites, and reactive oxygen species as components of induced resistance. J. Chem. Ecol. 21: 1511-1530.

Bi, J.L., Murphy, J.B. and Felton, G.W. 1997. Does salicylic acid act as a signal in cotton for induced resistance to Helicoverpa zea. J. Chem. Ecol. 23: 1805-1818.

De Carvalho, K., de Campos, M.K., Domingues, D.S., Pereira, L.F. and Vieira, L.G. 2013. The accumulation of endogenous proline induces changes in gene expression of several antioxidant enzymes in leaves of transgenic Swingle citrumelo. Mol Biol Report. 40: 3269-3279.
Debona, D., Rodrigues, F.Á., Rios, J.A. and Nascimento, K.J.T. 2012. Biochemical changes in the leaves of wheat plants infected by Pyricularia oryzae. Phytopathology 102:1121-1129.

Dhawan, A.K., Sidhu, A.S. and Simwat, G.S. 1988. Assessment of avoidable loss in cotton (Gossypium hirusutum and Gossypium arboreum) due to sucking pest and bollworms. Ind. J. Agri. Sci. 58(4): 290-292.

Dieng, H., Satho, T., Hassan, A.A., Aziz, A.T., Morales, R.E., Hamid, S.A., Miake, F. and Abubakar, S. 2011. Peroxidase activity after viral infection and whitefly infectation in juvenile and mature leaves of Solanum lycopersicum. J. Phytopathol. 159: 707712.

Dionisio-Sese, M.L. and Tobita, S. 1998. Antioxidant response of rice seedling to salinity stress. Plant Sci. 135: 1-9.

Ehsani-Moghaddam, B., Charles, M. T., Carisse, O., and Khanizadeh, S. 2006. Superoxide dismutase responses of strawberry cultivars to infection by Mycosphaerella fragariae. J. Plant Physiol. 163:147-153.

Foyer, C.H.M., Lelandais, C.G. and Kunert, K.J. 1991. Effect of elevated cytosolic glutathione reductase activity on the cellular glutathione pool and photosynthesis in leaves under normal and stress conditions. Plant Physiol. 97: 863-872.

Giannopolities, C. N. and Ries, S. K. 1977. Superoxide dismutase. I. Occurrence in higher plants. Plant Physiol. 59: 315-318.

Halliwell, B. and Gutteridge, J.M.C. 1989. Protection against oxidants in biological systems: The superoxide theory of oxygen toxicity. In: Free Radicals in Biology and Medicine. (Halliwell, B. and Gutteridge, J.M.C.) (Eds.) Oxford, Clarendon. pp. 86123.

He, J., Chen, F., Chen, S., Lv, G., Deng, Y., Fang, W., Liu, Z., Guan, Z. and He, C. 2011. Chrysanthemum leaf epidermal surface morphology and antioxidant and defense enzyme activity in response to aphid infestation. J. Plant Physiol. 168:687-93.

Hernández, J.A., Talavera, J.M., MartínezGómez, P., Dicenta, F., and Sevilla, F. 
2001. Response of antioxidative enzymes to plum pox virus in two apricot cultivars. Physiol. Plant. 111:313-321.

Kumar, M., Yadav, V., Tuteja, N. and Johri, A.K. 2009. Antioxidant enzyme activities in maize plants colonized with Piriformospora indica. Microbiology 155: 780-790.

Lukasik, I., Golawaska, S. and Wojcicka, A. 2012. Effect of cereal aphid infestation on Ascobate and Ascorbate Peroxidase activity in Triticales. Pol. J. Eniviron. Stud. 21: 1937-1941.

Madhusudhan, K.N., Srikanta, B.M., Shylaja, M.D., Prakash, H.S. and Shetty, H.S. 2009. Changes in antioxidant enzymes, hydrogen peroxide, salicylic acid and oxidative stress in compatible and incompatible host tobamovirus interaction. J Plant Interact. 4:157-166.

Maffei, M.E., Mithofer, A., Arimura, G.I., Uchtenhagen, H., Bossi, S., Bertera, C.M., Cucuzaa, L.S., Novero, M., Volpe, V., Quadro, S. and Boland, W. 2006. Effect of feeding of Spodoptera littoralis on Lima bean leaves. Ш. Membrane depolarization and involvement of hydrogen peroxide. Plant Physiol. 140:1022-1035.

Mydlarz, L.D. and Harvell, C.D. 2006. Peroxidase activity and inducibility in the see fan coral exposed to a fungal pathogen. Сomp Biochem Physiol. 10:1016.

Nakano, Y. and Asada, K. 1981. Hydrogen peroxide is scavenged by ascorbate specific peroxidase in spinach chloroplasts. Plant Cell Physiol. 22: 867-880.

Nath, P., Chaudhary, O.P., Sharma, P.D. and Kaushik, H.D. 2000. The studies on the incidence of important insect pests of cotton with special reference to Gossypium arborium (Desi) cotton. Indian J. Entomol. 62: 391-395.
Sanchez-Rodriguez, E., Rubio-Wilhelmi Mdel, M., Blasco, B., Leyva, R. and Romero, L. 2012. Antioxidant response resides in the shoot in reciprocal grafts of droughttolerant and drought-sensitive cultivars in tomato under water stress. Plant Sci 188189: 89-96.

Shah, K., Kumar, R.G., Verma, S. and Dubey, R.S. 2001. Effect of cadmium on lipid peroxidation, superoxide anion generation and activities of antioxidant enzymes in growing rice seedlings. Plant Sci. 161(6): 1135-1144.

Shannon, L. M., Key, E. and Law, J. Y. 1966. Peroxidase isoenzyme from horse radish roots: Isolation and physical properties. $J$. Biol. Chem. 241: 2166-2172.

Sharma, P. and Dubey, R.S. 2005. Drought induces oxidative stress and enhances the activities of antioxidant enzymes in growing rice seedlings. Plant Growth Reg. 46(3): 209-221.

Siddique, Z., Akhtar, K.P., Hameed, A., Sarwar, N., Ul-Haq, I. And Khan, S.A. 2014. Biochemical alterations in leaves of resistant and susceptible cotton genotypes infected systemically by cotton leaf curl burewala virus. J.Pl.Int. 9(1): 702-711.

Sinha, A. K. 1972. Calorimetric assay of catalase. Anal. Biochem. 47: 389-395.

Usha Rani, P. and Pratyusha, S. 2013. Defensive role of Gossypium hirsutum L: Antioxidative enzymes and phenolic acids in response to Spodoptera litura F. feeding. J. Asia-Pacific Entomol. 16: 131-136.

Vanacker, H., Carver, T.L.W. and Foyer, C.H. 1998. Pathogen-induced changes in the antioxidant status of the apoplast in barley leaves. Plant Physiol. 117:1103-1114.

\section{How to cite this article:}

Anju Rani, Jayanti Tokas, Himani and Singal H. R. 2019. Evaluation of Antioxidative Responses in Cotton (Gossypium hirsutum L.) Genotypes Imparting Resistance to Sucking Pest Attack. Int.J.Curr.Microbiol.App.Sci. 8(08): 2694-2707.

doi: https://doi.org/10.20546/ijcmas.2019.808.312 